\title{
In Vitro Cytotoxic Activity of Isostichopus badionotus, a Sea Cucumber from Yucatan Peninsula Coast
}

\author{
Aida R. Pérez-Espadas ${ }^{1}$, María J. Verde-Star ${ }^{1}$, Catalina Rivas-Morales ${ }^{1}$, \\ Azucena Oranday-Cárdenas ${ }^{1}$, María E. Morales-Rubio ${ }^{1}$, Lorena V. León-Deniz ${ }^{2}$, \\ Jaqueline Canul-Canché ${ }^{3}$ and Leovigildo Quijano ${ }^{4, *}$
}

${ }^{1}$ Facultad de Ciencias Biológicas, Universidad Autónoma de Nuevo León, Av. Pedro de Alba s/n, Ciudad Universitaria, CP 66450, Nuevo León, México

${ }^{2}$ Facultad de Medicina Veterinaria y Zootecnia, Universidad Autónoma de Yucatán, Carr. Xmatkuil, Km. 15.5, Apartado Postal No. 116, CP 97315, Yucatán, México

${ }^{3}$ Facultad de Química, Universidad Autónoma de Yucatán, C. 41 No. 421 Col. Industrial, CP 97150, Mérida, Yucatán, México

${ }^{4}$ Instituto de Química, Universidad Nacional Autónoma de México, Circuito Exterior, Ciudad Universitaria, 04510, México, D. F., México

\begin{abstract}
The in vitro cytotoxic activity of hexane, ethyl acetate and butanol extracts of the sea-cucumber Isostichopus badionotus (Holothuroidea) was tested against normal cells (Vero), human cervical carcinoma (HeLa) and breast adenocarcinoma (MCF-7 and MDA-MB-231) ATCC cells by 3-(4,5-dimethylthiazol-2-yl)-2,5-diphenyl tetrazolium bromide (MTT) assay. Hexane extracts from body walls and viscera showed high cytotoxic activity against HeLa cells $\left(\mathrm{IC}_{50}\right.$ 's $=$ 48.5 and $42.5 \mu \mathrm{g} \mathrm{mL}^{-1}$, respectively), while the ethyl acetate extract of body walls was considered low active $\left(\mathrm{IC}_{50}=98.3\right.$ $\mu \mathrm{g} \mathrm{mL}{ }^{-1}$ ). In addition, the body walls hexane extract showed a good selectivity index value of 12.0 .
\end{abstract}

Keywords: Holothurian, organic extracts, selectivity index, HeLa cells.

\section{INTRODUCTION}

Cancer is a leading cause of death around the world with 12.7 million new cases and 7.6 million deaths worldwide reported in 2008 , and it is estimated that the death toll will be 13.1 million deaths in 2030 [1]. Presently, more than 100 types of cancer have been identified, and despite enormous advances in treatment of cancer patients, a growing body of clinical and experimental evidence has revealed a strong impact of drug resistance on clinical outcomes in cancer chemotherapy. Therefore, the need for finding novel agents to improve anticancer drug therapy is imperative $[2,3]$.

Natural products, defined as small-molecule secondary metabolites produced for organisms, have proved to be very useful in development of anticancer drugs over last five decades. Currently, a significant numbers of compounds obtained from marine environment are in clinical trials; hence marine organisms are considered valuable sources of cytotoxic, antiproliferative, antitumor or anticancer compounds [4-7]. Therefore, several sea cucumbers species collected worldwide have been studied in order

*Address correspondence to this author at the Instituto de Química, UNAM, Circuito Exterior, Ciudad Universitaria, 04510, D.F. México; Tel: $(+52) 55$ 56224411; Fax: (+52) 55 56162203; E-mail: quijano@unam.mx

ISSN: 2223-3806 / E-ISSN: 1927-5951/14 to determine its potential as sources of anticancer compounds.

Sea cucumbers species are commercially exploited fresh or in dehydrated form (bêche de mer, trepang, gamat) in Asian markets, mainly in China, Korea, Indonesia and Japan as functional foods [8-11] because of their high-protein content and their putative aphrodisiac, tonical and medicinal properties [12,13]. However, some species have been overexploited; which may result in a population collapse and the loss of significant potential source of anticancer drugs for the future.

Isostichopus badionotus (Selenka, 1867), is distributed mainly in Gulf of Mexico, Caribbean Sea, and the joining of these two outstanding marine ecosystems, the Yucatan Channel $[14,15]$. It is one of four species of sea cucumbers overexploited in Yucatan, Mexico, due to illegal fishing. A literature survey indicated that there is too little information about the metabolites of this species and their biological activity, since only one study about citotoxicity of a hydrolysate of $l$. badionotus against colorectal HT-29 cancer cells $\left(\mathrm{IC}_{50}=1450 \mu \mathrm{g} \mathrm{mL}^{-1}\right)$ is reported [16].

In consequence, the present study was conducted to test the activity of body walls and visceral organ extracts from I. badionotus against Vero, HeLa, and

@ 2014 Lifescience Global 
breast adenocarcinoma (MCF-7 and MDA-MB-231) ATCC cells.

\section{MATERIALS AND METHODS}

\section{Animal Material and Extraction Procedure}

Specimens of Isostichopus badionotus (27.8 kg wet weight) were collected by scuba diving at depths ranging from 14.5 to $16 \mathrm{~m}$ in the coast of Progreso ( $\mathrm{N}$ $21^{\circ} 27.3^{\prime}-\mathrm{W} 89^{\circ} 42.7^{\prime}$ ), Yucatan (Mexico) in June and November 2010. The specimens were collected and authenticated by M. Sc. Carlos Zetina Moguel and voucher specimen (YUC-CC-250-11/CAR/293) was deposited in the collection of Campus de Ciencias Biológicas y Agropecuarias, Universidad Autónoma de Yucatán, in Mérida, Yucatán, México.

The animals were immediately placed in ice water in sealed plastic bags and transported to the laboratory where they were dissected. Body walls $(21.6 \mathrm{~kg}$ wet weight) and visceral organ (6.2 kg wet weight, gut content included) were stored separately at $-17^{\circ} \mathrm{C}$.

Both body walls and visceral organ samples underwent the same analytical procedure. The frozen tissues were homogenized, chopped and extracted exhaustively with methanol at room temperature. The extracts were subsequently evaporated at reduce pressure for removal of the solvent. The syrup was successively extracted three times each with hexane $(\mathrm{Hx})$, ethyl acetate (EtOAc) and n-butanol $(\mathrm{BuOH})$.

\section{Cytotoxicity Assay}

Breast adenocarcinoma (MCF-7 and MDA-MB231), human cervical carcinoma (HeLa), and African green monkey kidney (Vero) ATCC cells were used. The cells were cultivated in D-MEM (Invitrogen, México), supplemented by $10 \%$ fetal calf serum and antibiotics (100 units $\mathrm{mL}^{-1}$ penicillin and $100 \mathrm{pg} \mathrm{mL}^{-1}$ streptomycin), at $37{ }^{\circ} \mathrm{C}$ in a humid atmosphere containing $5 \% \mathrm{CO}_{2}$.

The cytotoxicity test [17] was conducted by using 96-well microtiter plates containing 2,500 cells per well. The cell suspensions were incubated for $24 \mathrm{~h}$ under the conditions mentioned above. After incubation 18.75, $37.5,75,150$ and $300 \mu \mathrm{g} \mathrm{mL}^{-1}$ of each extract were added per well. The microplates were further incubated for $48 \mathrm{~h}$ and then $10 \mu \mathrm{L}$ of 3-(4,5-dimethylthiazol-2-yl)2,5-diphenyl tetrazolium bromide (MTT) (SigmaAldrich, USA) solution ( $5 \mathrm{mg} \mathrm{mL}^{-1}$ ) was added to each well. After $4 \mathrm{~h}$ additional incubation, the liquid was discarded and replaced with $100 \mu \mathrm{L}$ of dimethyl sulfoxide (DMSO) (Sigma-Aldrich, USA) and the absorbance measured in a microplate reader (Multiskan Asent) at $550 \mathrm{~nm}$. Each assay was carried out in three independent experiments. The cell viability in response to treatment was calculated using Origin 8.6 software. The selectivity index (SI) was calculated with the equation: $\mathrm{SI}=I \mathrm{IC}_{50}$ normal cells $/ \mathrm{IC}_{50}$ cancer cells.

\section{RESULTS AND DISCUSSION}

The cytotoxic activity of hexane, ethyl acetate and n-butanol extracts from body walls and viscera of Isostichopus badionotus collected at the Yucatan Channel were tested in vitro against human tumor cell lines of cervix (HeLa) and breast adenocarcinoma (MCF-7 and MDA-MB-231). In order to evaluate the level of harmfulness of the extracts, the selectivity index was determined on African green monkey kidney normal cells (Vero). Results are showed in Table 1.

Based on Manosroi et al. [18] screening, in the present study the activity of extract was ranked in two levels: high $\left(\mathrm{Cl}_{50} \leq 50 \mu \mathrm{g} \mathrm{mL}^{-1}\right)$, and low $\left(\mathrm{Cl}_{50} 51-100 \mu \mathrm{g}\right.$ $\mathrm{mL}^{-1}$ ), and the selectivity according to VonthronSénécheau et al. [19] who consider that an $S I \geq 10$ indicated that biological efficacy of the extract is not due to cytotoxicity.

The HeLa cell line was the most susceptible to nonpolar extracts of body walls and viscera of $l$. badionotus, while MCF-7 and MDA-MB231 were not affected by any of the tested extracts with exception of the EtOAc extract, which inhibited the cellular growth at 105.4 and $101.2 \mu \mathrm{g} \mathrm{mL}^{-1}$, respectively. The hexanic extract of body walls exhibited cytotoxic activity at 48.5 $\mu \mathrm{g} \mathrm{mL}^{-1}$ and the one from viscera at $42.5 \mu \mathrm{g} \mathrm{mL}^{-1}$. The polar extract $(\mathrm{BuOH})$ did not show cytotoxic activity against the three cancer cell lines (HeLa, MCF-7, and MDA-MB231), while the normal cell line (Vero) was not susceptible to any extract. Most of the extracts showed selectivity indexes in the range of $1.0-3.8$ with exception of hexane extracts, which exhibited selectivity indexes of 12 and 5.2 against HeLa cells, respectively.

According to the ranks described above, the cytotoxic activity of hexane extracts of body walls (48.2 $\left.\mu \mathrm{g} \mathrm{mL} \mathrm{m}^{-1}\right)$ and viscera $\left(42.5 \mu \mathrm{g} \mathrm{mL}^{-1}\right)$ of $I$. badionotus against HeLa cells were considered high, while the cytotoxic activity of EtOAc extract of body walls was low $\left(98.3 \mu \mathrm{g} \mathrm{mL}^{-1}\right)$. 
Table 1: Cytotoxic Activity and Selectivity Index of Extracts from Isostichopus badionotus

\begin{tabular}{|c|c|c|c|c|c|}
\hline \multirow[t]{2}{*}{ Animal part } & \multirow[t]{2}{*}{ Extract } & \multicolumn{4}{|c|}{$\begin{array}{c}\text { Cell lines } \\
I C_{50}{ }^{a} \mu g \mathrm{~mL}^{-1} \pm S D^{b}\left(S I^{c}\right)\end{array}$} \\
\hline & & HeLa & MCF-7 & MDA-MB231 & Vero \\
\hline \multirow[t]{3}{*}{ Body walls } & Hex & $48.5 \pm 1.9(12.0)$ & $197.5 \pm 11.5(3.0)$ & $152.5 \pm 4.8(3.8)$ & $582.8 \pm 21.5$ \\
\hline & EtOAc & $98.3 \pm 5.0(1.6)$ & $105.4 \pm 12.0(1.5)$ & $101.2 \pm 12.1(1.6)$ & $158.2 \pm 21.3$ \\
\hline & $\mathrm{BuOH}$ & $>600$ & $>600$ & $>600$ & $>600$ \\
\hline \multirow[t]{4}{*}{ Viscera } & Hex & $42.5 \pm 2.0(5.2)$ & $167.1 \pm 10.0(1.3)$ & $152.8 \pm 11.0(1.4)$ & $218.9 \pm 13.7$ \\
\hline & EtOAc & $166.7 \pm 8.9(1.3)$ & $204.7 \pm 7.9(1.0)$ & $117.7 \pm 7.9(1.8)$ & $209.3 \pm 2.3$ \\
\hline & $\mathrm{BuOH}$ & $>600$ & $>600$ & $>600$ & $>600$ \\
\hline & Paclitaxel & $0.08 \pm 0.01(15.5)$ & $0.07 \pm 0.02(17.7)$ & $0.03 \pm 0.01(41.3)$ & $1.24 \pm 0.01$ \\
\hline
\end{tabular}

anhibitory Concentration 50.

${ }^{b}$ Standard Deviation.

'Selectivity Index.

A study of the less polar lipid fraction of the chloroform-methanol extract from body walls of Cucumaria frondosa, a North Atlantic commercially harvested sea cucumber, resulted in the isolation of cerebrosides, which exhibited an antiproliferative effect on Caco-2 colon cancer cells $\left(\mathrm{IC}_{50}=4.13 \mu \mathrm{g} \mathrm{mL}^{-1}\right)$ [20]. Probably, the cytotoxic activity of hexane extracts of viscera and body walls of $I$. badionotus could be explained by the presence of cytotoxic cerebrosides.

Although, the cytotoxic activity of non-polar extract of $I$. badionotus body walls was classified as high, its SI value was 12.0 unlike the other extracts which showed poor selectivity (1.0-5.2). Besides, it is remarkable that the selectivity showed by the hexane extract of body walls of $I$. badionotus was close to the SI of paclitaxel (15.5), the commercial anticancer drug used as positive control.

On the other hand, the lack of cytotoxic activity of $\mathrm{BuOH}$ extracts was unexpected because it is known that triterpene glycosides (saponins), commonly isolated from polar extracts of holothurians, shown cytotoxic activity which is related to membranotropic action due to the presence of an 18(20)-y-lactone in the aglycon moiety in most cases, as well as a linear tetrasaccharide fragment. Moreover, oligoglycosides containing quinovose instead of glucose or xylose as second monosaccharide unit usually exhibited a high bioactivity [21].

Regarding the presence of saponins in $l$. badionotus, up today, only a mixture of $D$-xylosides of $3 \beta$-hydroxy sterols of the cholestane series has been isolated from the body walls of this species [22]. Therefore, the non-cytotoxic activity of the $\mathrm{BuOH}$ extracts of $I$. badionotus might be related with absence of saponins that fulfill the characteristics above described.

\section{CONCLUSIONS}

Only the non polar extracts from I. badionotus were considered significantly active and selective against human tumor cell lines of cervix (HeLa). The good selectivity index exhibited by the hexane extract of the body walls of $I$. badionotus encouraging further research on the isolation of the cytotoxic compounds.

On the other hand, the lack of cytotoxic activity of butanolic extracts might be related with absence of holostan-type triterpene glycosides.

\section{ACKNOWLEDGEMENTS}

This work was funded by Grant 101641 provided by the Consejo Nacional de Ciencia y Tecnología (CONACyT), Mexico. Results of this paper are taken in part from the doctoral thesis presented by A.R.P.E, who acknowledges CONACyT for the student scholarship No 223006. The authors also thank to Dr. Manuel F. Flores-Arce for English revision of the manuscript.

\section{REFERENCES}

[1] Ferlay J, Shin HR, Bray F, Forman D, Mathers C, Maxwell D. Estimates of worldwide burden of cancer in 2008 : GLOBOCAN 2008. Int J Cancer 2007; 127: 2893-2917. http://dx.doi.org/10.1002/ijc.25516

[2] Nussbaumer S, Bonnabry P, Veuthey JL, Fleury-Souverain S. Analysis of anticancer drugs: A review. Talanta 2011; 85 2265-2289.

http://dx.doi.org/10.1016/j.talanta.2011.08.034

[3] Rebucci M, Michiels C. Molecular aspects of cancer cell resistance to chemotherapy. Biochem Pharmacol 2013; 85: 1219-1226. http://dx.doi.org/10.1016/j.bcp.2013.02.017 
[4] Blunden G. Biologically active compounds from marine organisms. Phytother Res 2001; 15: 89-94. http://dx.doi.org/10.1002/ptr.982

[5] Blunt JW, Copp BR, Munro MHG, Northcote PT, Prinsep MR. Marine natural products. Nat Prod Rep 2004; 31: 160-258. http://dx.doi.org/10.1039/c3np70117d

[6] Simmons TL, Andrianasolo E, McPhail K, Flatt P., Gerwick $\mathrm{WH}$. Marine natural products as anticancer drugs. Mol Cancer Ther 2005; 4: 333-342.

[7] Conand C.,Byrne M. A review of recent developments in the world sea cucumber fisheries. Marine Fisheries Review 1993; 55: 1-15.

[8] Chen J. Overview of sea cucumber farming and sea ranching practices in China. SPC Beche-de-mer Information Bulletin 2003; 18: 18-23.

[9] Chen J. Present status and prospects of sea cucumber industry in China. In: Conand C, Purcell S, Uthicke S, Hamel JF, Mercier A, editors. Advances in sea cucumber aquaculture and management. FAO Fisheries Technical Paper No. 463 Rome: FAO 2004; p. 25-38.

[10] Park SY, Lim HK, Lee S, Hwang HC, Cho SK, Cho M. Pepsin-solubilized collagen (PSC) from red sea cucumber (Stichopus japonicus) regulates cell cycle and the fibronectin synthesis in HaCat cell migration. Food Chem 2012; 132: 487-492.

http://dx.doi.org/10.1016/j.foodchem.2011.11.032

[11] Wen W, Chaoqun H, Zhang L, Luo P, Zhao Z, Fan S, Su T. The application of PCR-RFLP and FINS for species identification used in sea cucumbers (Aspidochirotida: Stichopodidae) products from the market. Food Control 2010; 21: 403-407.

http://dx.doi.org/10.1016/j.foodcont.2009.06.014

[12] Aydin M, Sevgili H, Tufan B, Emre Y, Köse S. Proximate composition and fatty acid profile of three different fresh and dried commercial sea cucumbers from Turkey. International Journal of Food Science and Technology 2011; 46: 500-508. http://dx.doi.org/10.1111/j.1365-2621.2010.02512.x

[13] Bordbar S, Anwar F, Saari N. High-Value components and bioactives from sea cucumbers for functional foods- A review. Mar Drugs 2011; 9: 1761-1805. http://dx.doi.org/10.3390/md9101761
[14] Guzmán HM, Guevara CA. Population structure, distribution and abundance of three commercial species of sea cucumber (Echinodermata) in Panama. Caribb. J. Sci. 2002; 38: 230-238.

[15] Purcell, SW, Samyn Y, Conand C. Commercially important sea cucumbers of the world. FAO Species Catalogue for Fishery Purposes No. 6. Rome: FAO; 2012.

[16] Pérez-Vega JA, Olivera-Castillo L, Gómez-Ruiz JA, Hernández-Ledesma B. Release of multifunctional peptides by gastrointestinal digestion of sea cucumber (Isostichopus badionotus). J Funct Foods 2013; 5: 869-877. http://dx.doi.org/10.1016/j.jff.2013.01.036

[17] Schlie-Guzmán M, García-Carrancá A, González-Esquinca A. In Vitro and In Vivo Antiproliferative Activity of Laherradurin and Cherimolin-2 of Annona diversifolia Saff. Phytother Res 2009; 23: 1128-1133. http://dx.doi.org/10.1002/ptr.2760

[18] Manosroi J, Dhumtanom P, Manosroi A. Anti-proliferative activity of essential oil extracted from Thai medicinal plants on KB and P388 cell lines. Cancer Lett 2006: 235: 114-120. http://dx.doi.org/10.1016/j.canlet.2005.04.021

[19] Vonthron-Sénécheau C, Weniger B, Ouattara M, et al. In vitro antiplasmodial activity and cytotoxicity of ethnobotanically selected Ivorian plants. J Ethnopharmacol 2003, 87: 221-225 http://dx.doi.org/10.1016/S0378-8741(03)00144-2

[20] Xu J, Guo S, Du L, Wang YM, Sugawara T, Hirata T, Xue $\mathrm{CH}$. Isolation of cytotoxic glucoerebrosides and longchain bases from sea cucumber Cucumaria frondosa using high speed counter-current chromatography. J Oleo Sci 2013, 62 133-142. http://dx.doi.org/10.5650/jos.62.133

[21] Kalinin V, Aminin DL, Avilov SA, Silchenko AS, Stonik VA. Triterpene glycosides from sea cucumbers (Holothurioidea, Echinodermata). Biological activities and functions. In: Attaur-Rahman editor. Studies in Natural Products Chemistry. Elsevier B.V. 2008; p. 135-196.

[22] Elyakov GB, Kuznetsova TA, Conde C, Kalinovskaya NI, Kalinovskii Al, Smetanina OF. Glycosides of marine invertebrates VIII. Steroid glycosides of the holothurian Isostichopus badionotus. Chemistry of Natural Compounds 1979, 6: 799-708.

Received on 26-06-2014

Accepted on 25-07-2014

Published on 12-08-2014

DOI: http://dx.doi.org/10.6000/1927-5951.2014.04.03.3

(C) 2014 Pérez-Espadas et al.; Licensee Lifescience Global.

This is an open access article licensed under the terms of the Creative Commons Attribution Non-Commercial License (http://creativecommons.org/licenses/by-nc/3.0/) which permits unrestricted, non-commercial use, distribution and reproduction in any medium, provided the work is properly cited. 